\title{
SECTION 11(b) OF THE HOLDING COMPANY ACT: FIFTEEN YEARS IN RETROSPECT
}

EASILY the most ambitious legislation of the depression-inspired federal attack on concentrated economic power was Section 11(b) of the Public Utility Holding Company Act of $1935 .{ }^{1}$ It pronounced the "death sentence" ${ }^{2}$ on an industry whose history had been marked by spectacular financial profiteering and unbridled growth of corporate empires. Its aim was the protection of the consuming and investing public which utility management had continuously and effectively exploited. And it went beyond sanctions against corporate abuse to require a revolution in utility corporate structures as well.

In the relatively short period of fifteen years, the Securities and Exchange Commission has virtually completed the corporate transformation required under Section 11(b). ${ }^{3}$ It is now possible to decide whether the high hopes raised by the Act have been justified.

\section{The Case Against the Holding Company}

The reasons for the passage of the Act are an old and familiar story. By 1935 a few large holding company systems dominated the entire utility industry. This control of vast corporate empires-manifestly impossible by direct investment ${ }^{5}$-was accomplished by pyramiding. Numerous subholding companies were created, each owning the voting stock of the cor-

\footnotetext{
1. 49 StAt. 803,821 (1935), 15 U.S.C. $\$ 79 k$ (b) (1946).

2. See Douglas, The Case for Integration in Denocracy and Finance 144 (Allen cd. 1940).

3. See note 111 infra.

4. The historical development of holding company domination reached a climax shortly after the onset of the depression when sixteen vast empires controlled ninety per cent of the electricity produced in the United States. The most extensive of these corporate giants was the United Corporation, a super-holding company which, through a minority of voting stock, controlled properties extending from the St. Lawrence River to the Gulf of Mexico. Its assets were over four billon dollars. Federal Trade Commission, Utility Corporations, Sen. Doc. No. 92, Part 72-A, 70th Cong., 1st Sess. 159 (1932) (hereafter cited as Utility Corporations). See Note, 37 CoL. L. REv. 785, 936 (1937). The value of the Insull-controlled group was something over two billion. Other important holding companies with assets around the one billion dollar mark were Electric Bond and Share Company, Cities Service Company, Consolidated Gas Company of New York, Associated Gas and Electric System, Standard Gas and Electric Company, and the North American Company. Moody's Public Utrlities, 1931 passint.

5. In the Electric Bond and Share system, for instance, control of the $\$ 3,885,600,000$ empire, through direct investment in the comon stock of the basic operating units wolld have required an investment of almost two billion dollars. Bonbrigut \& MEANs, THE HOLDINa Companx 105 (1932). Pyramiding permitted control to be lodged exclusively in $9,615,300$ shares (par value $\$ 96,153,000$ ) of common stock issued by Bond and Share itself whose total capitalization, including both preferred and common, was only $\$ 145,153,000$. Utility Corporations, op. cit. supra note 4, p. 169.
} 
porations in the tier below. ${ }^{6}$ Non-voting securities-usually many times the voting stock in value-were distributed to the public. ${ }^{7}$ In this way, negligible investment in the company at the apex of such systems would control a whole network of operating properties. ${ }^{8}$

In periods of prosperity those holding equity securities in the upper tiers received profits which were extremely high in proportion to their investment. ${ }^{9}$ But pyramiding cut the other way during business decline. By

6. In some systems pyramiding was carried to extreme lengths. In the American Gas and Electric Company, for instance, one corporate branch contained ten companies between the top holding company and the operating corporations at the base. Utility Corporalions, op. cit. supra note 4, p. 159.

7. The public held sixty-seven per cent of the six billion dollars of outstanding operating utility securities in 1931. 2 Dewniv, Financina Policy of Conporntro:ss 1051n. (4th ed. 1946). Fifty-two per cent of this was in the form of debt obligations, 32\% nonvoting preferred stock and only $16 \%$ common stocks. Moreover, the common was so widely diff used that a very small block of concentrated voting stocks was sufficient for the cxercise of corporate control. Utility Corporations, op. cit. sipra nate 4, p. 166. The situation was an extreme historical example of the separation of "ownership" from "control" described in Berle \& Means, The Modern Corporation and Paivate Property 69-118 (2d ed. 1940). Widespread public acceptance of these stocks was made possible in part by the misguided faith of investors (really amateur speculators) in the efficacy of the holdins company device itself - "a belief that there was some inherent dynamic virtue in the holding company device which would inevitably result in expanded earnings for operating units acquired by holding company groups." Kingaran, The Prysical Integration of the Public Utility Holdna Coxpanies Since 1935, p. 35 (unpublished thesis in the University of Wisconsin Library, 1949). The Federal Trade Commission also advanced the opinion that the expansion of investment houses during the First World War had saddled them with large organizational overhead. Where they dominated utility companies, therefore, their interest dictated a multiplicity of security issues. Utility Corporations, op. cit. supra note 4, pp. 75-8.

8. Each corporate tier had outstanding a lesser volume of voting common than the tier below, its own assets of voting stocks having been partially financed by public-held debt and preferred securities. In this way, control leverage was multiplied as the number of tiers in the corporate system increased. For example, in the Insull system, which in some lines had 8 corporate levels, one dollar invested at the top controlled $\$ 2,000$ worth of property in the operating utilities at the bottom. Utility Corporalions, op. cil. suspra note 4, pp. 160-1. See also Bonbright \& Means, The Holding Cosirany 114-117 (1932).

Leverage was intensified by the large ratio of non-voting to voting sceurities. About half of the average operating company's capital structure was bonds and debentures and another eight per cent preferred stocks. Thosirson \& Sarrte, Public Utility Econonics 127 (1941). In the Niagara Hudson Power Group, for instance, the operating companies were capitalized with sixty-seven million dollars of bonds, twenty-four million of preferred and only eight million of voting common. All of this common was owned by the subholding companies in the tier immediately above. Utility Corporations, op. cit. rssprs note 4, p. 99.

Mioreover, system control did not demand a majority ownership of the roting securities. Electric Bond and Share was able to dictate operating policy through a $16.8 \%$ ownership in American Gas and Electric Company, 20.2\% in American Power and Light, 45.7\% in National Power and Light, and 23.1\% in Electric Power and Light, its immediate subsidiaries. Bonbright \& Mínans, The Holdrng Coarpasy 102 (1932).

9. Schematically, a pyramided system where each corporate tier holds all the common 
virtue of the large drain of fixed charge and cumulative preferred income requirements all the way up the line, a slight drop in consumer revenues at the operating base left upper equity holdings high and dry.10 Hence there was a strong pressure on holding company management to secure income sufficient to supply dividends at the top. ${ }^{11}$

A catalogue of dubious financial practices was developed for use whenever holding company management was faced with reduced operating revenue. Local production units were bled by excessive dividend payments. ${ }^{12} \mathrm{Di}$ rectors, officers and managers received extra-large official salaries. ${ }^{13}$ Operating companies were forced to accept high-priced servicing and underwriting contracts with other corporations in the system, ${ }^{14}$ and were seldom permitted to make adequate provision for depreciation in their balance sheets. ${ }^{10}$ In many cases, physical assets were improvidently written up whenever de-

stock of the corporations below it produces an enormous profit for the top cquity securities whenever income ratio is greater than the fixed charge requirements-c.g., an over-all net income of eight per cent of the investment as opposed to a five or six per cent bond and preferred stock capital structure. The smaller the proportion of common stock, the larger will be its return. See Barnes, The Economics of Public Utility Regulation 73-8 (1942).

10. Where fixed charges and preferred dividends were cumulative, common lost not only a year's income but the prospect of dividends for some time to come. See Buchanan, Public Utility Holding Company Problem, 25 CaLIF. L. Rev. 517, 522-6 (1937). Only two systems restricted funded debt securities to operating companies, Insull and United Gas Improvement. Utility Corporations, op. cit. stipra note 4, p. 102.

11. The speculative nature of holding company investments did not appear seriouts prior to 1929. Management and investor seemed to assume that demand for power and gas was inelastic with respect to national income as well as to price, and thus that any general depression would not seriously affect the utility industry, despite its prior security overcapitalization. See Thompson \& Smith, Public Utтlity Economics 80 (1941).

12. See Utility Corporations, op. cit. supra note 4, pp. 440-8.

13. See id. at $130-5,152$.

14. Servicing and construction contracts were an important source of income. Forty per cent of the income of Electric Bond and Share came from servicing fees, $13 \%$ from sales of investment securities, $10 \%$ on underwriting and financing, and only $27 \%$ in the form of return on investment. Utility Corporations, op. cit. supra note 4, pp. 352-5, 423. Moreover, it exercised a monopoly over these revenue sources: its subsidiaries were bound to call on the parent for all managerial and engineering supervision and for all security marketing. Bonbright \& Means, The Holding Company 104-105 (1932).

Since it is through centralization of servicing and investment assistance that the holding company performs its legitimate economic functions, criticism was lodged, not against these practices as such, but rather against exploitation of the utility consumer through excessive charges. Electric Bond and Share's profit on management and construction contracts was over one hundred per cent. Utility Corporations, op. cit. supra note 4, p. 464. Barstow and Company had an income of over two million dollars through management assistance contracts and construction services, the costs of which were $\$ 250,000$. Ibid.

15. See Utility Corporations, op. cit. supra note 4, pp. 496, 847 ct scq. The practice at times became a vicious circle. In the Middle West Utilities system it was the procedure to create a new surplus by a further reduction of depreciation reserves whenever moncy was needed to replace worn out equipment. $I d$. at 8 . What should have been available had been paid out as "net income dividends" through previous inadequate depreciation. Id. at 851 . 
creased revenues failed to provide the required profit. ${ }^{36}$ In addition, purely fictitious surplus accounts were created. ${ }^{17}$ And electricity was sold by one operating unit to another unit in the same system at a large markup. ${ }^{13}$ These tactics were all designed to provide net income sufficient to meet the burden of high fixed charges and still pay excessive dividends on the common stock at the top. ${ }^{19}$

The effect of these maneuvers on the investing public was particularly severe. Informed judgment about the worth of securities in such overcapitalized and complex corporate structures was impossible. ${ }^{n}$ During the

16. Total asset write-ups seem to have been about one and one half billion dollars. Utility Corporations, op. cit. supra note 4, p. 302. Through these asset vrite-ups, "capital surplus" accounts were created; these were used to extinguish unamortized discount and expense on bonds and stocks, thus capitalizing these expenses and, in the process, effectively misstating the true operating rate base. Id. at $52 \mathrm{~s}$.

This stock watering permitted the marketing of preferred at a price so excessive as to absorb the full capital requirements of a particular system. Thus, management could tale no-par voting common with little or no investment. Id. at \$46-7.

17. Fictitious surplus accounts generally took the form of recorded but undistributed earnings of subsidiaries. By building up a surplus on the basis of uncollected income, listed as an asset, dividends could be declared at a time when the parent corporation had no actual revenues and when, in fact, the subsidiary itself had not earmarked any of its surplus for the purpose of dividend declaration for the holding company. See Utility Corporations, op. cit. supra note 4, pp. 468-70.

18. By sales of electricity from one company in a system to another, either at a large profit or loss, revenues were equalized and the states were not provoled into reducing rates. Utility Corporations, op. cit. sipra note 4, pp. 851-4.

19. To list all the abuses practiced by these obviously resourceful coptains of industry would be impossible. Some additional, but less common, devices indicate the types of corporate chicanery which the holding company made possible. In one case, a top holding company, Northern States Power of Delaware, was created merely to hold the securities of Northern States Power of Montana, in order thereby to escape the double liability of corporate stockholders in the latter state. See Northern States Power Co. v. SEC, 164 F2d 810, 812 (3d Cir. 1947). Subholding companies were used to permit individual delays on income taxes, and to segregate assets against which there were no purchase moncy liens. Utility Corporations, op. cit. sipra note 4, p. 127. No-par stock, which was widely used, provided a flexible item in the equity side of the balance sheet since stated value could be arbitrarily established to permit any showing of income desired. Id. at 513. And loans from the operating companies to the holding companies were made at lower rates than contemporaneous loans in the opposite direction. Id. at 461.

Such balance sheet juggling made dividends possible even at the depth of the depression. At one point, the Foshay group-whose slogan was "all your money-all the time-on time"-was able to declare $\$ 1,104,000$ dividends on $\$ 1,692,271$ "income," $\$ 1,501,698$ of which consisted of "appreciation" of a subsidiary's securities. During the period there was actually a loss of $\$ 250,000$. Id. at 445 . The directors were subsequently convicted of fraud. Foshay v. United States, 68 F.2d 205 (8th Cir. 1933). See Trosipsos, Cosrfessiosss of rirt POWER TRUST (1932).

20. Security structures were extremely complicated. Associated Gas \& Electric Co., for instance, had outstanding ten different kinds of fixed-interest debt obligations, several series of income debentures, a number of securities variously known as convertible debenture certificates, convertible certificates, and convertible obligations, two different classes 
depression the decrease in operating earnings compelled companies in the upper tiers of most systems to forego preferred stock dividends. ${ }^{21}$ As a result of these arrearages, dividends could not be payed on common stocks and they became virtually worthless. A large part of the beguiled public's investments was thus wiped out.

The damage to consumers was equally heavy.22 The technological advance and centralization of the utility industry during the first quarter of the century should have resulted in substantial reduction of consumer rates. Instead, these savings were invariably drained off as dividends to the holding companies, either by excessive construction and servicing charges imposed on the operating units, ${ }^{23}$ or by asset inflation and improper capitalization of intangibles. ${ }^{24}$

of preferred stock, a class A stock, a class B stock, a common stock, and warrants to purchase common stock. 15 S.E.C. ANN. REP. 105 (1949).

The gullible investing public was an easy target for a holding company management which did not balk at unloading even the most worthless securities on the market. Nevertheless, market rigging was extensively employed to insure the desired price. In fact, Insull of Middle West Utilities was able successfully to keep up the falling utilities market of October, 1929 , long enough to enable him to sell $\$ 18,000,000$ worth of securities. Doherty, of Cities Service, was able to market $\$ 1,146,000$ of securities in the face of the 1929 crash, but only by spending $\$ 965,000,000$ in the purchasing process.

The importance of such practices to the general security market is seen from the fact that from 1919 to 1925, new issues of utility stocks represented almost half of all recorded new issues. Dorau, Public Utility Financing, 1 J. LAND \& P.U. Econ, 305 (1925).

21. Douglas, The Case for Integration in Democracy and Finance 157 (Allen ed. 1940) gives the following figures:

\begin{tabular}{|c|c|c|c|c|}
\hline & $\begin{array}{c}\text { No. of Companies } \\
\text { Examined }\end{array}$ & $\begin{array}{l}\text { No. of Companies } \\
\text { in Arrears }\end{array}$ & $\begin{array}{l}\text { Extent of } \\
\text { Arrcars }\end{array}$ & $\begin{array}{l}\text { Value of the } \\
\text { Stock }\end{array}$ \\
\hline Holding & 154 & 48 & $\$ 336,670,000$ & 25.3 \\
\hline Companies & $\begin{array}{c}(\$ 2,413,000,000 \\
\text { par of preferred) }\end{array}$ & $\begin{array}{r}(\$ 1,330,000,000 \\
\text { par of preferred })\end{array}$ & & \\
\hline Operating & 224 & 70 & $95,000,000$ & 21.0 \\
\hline Utilities & $\begin{array}{r}(\$ 1,447,000,000 \\
\text { par of preferred) }\end{array}$ & $\begin{array}{c}(\$ 442,000,000 \\
\text { par of preferred) }\end{array}$ & & \\
\hline
\end{tabular}
(1932).

See Lilienthal, Public Utility Financing Dutring the Depression, 46 HArv. L. Rev. 745

22. Almost all holding company control evolved originally as a by-product of contractural relationships between the independent industry and utility servicing companics which directly benefited the public. Gas and electric corporations grew rapidly after their birth in the eighties and consequently often found themselves embarrassed for capital. In order to pay for the construction and servicing assistance they required, therefore, they were forced to give, first, income bonds and, later, equity securities. And the manufacturers of electrical equipment such as Electric Bond and Share's original corporate parent, Ge1!u eral Electric Corp., the underwriters such as Insull, and the construction companies such as Engineers Public Service, were anxious, in turn, to assist the industry which was their source of income. Of course, the rapid expansion of gas and electric utility service which resulted between 1890 and 1910 was distinctly in the interest of the public. See RugGues, Problems in Public Utility Economics and Managenent 192-9 (1933).

23. See note 14 supra.

24. See notes 16 and 17 supra. 
State regulation proved incapable of dealing with these abuses. Direct control of exploitation by the interstate holding company was legally impossible. ${ }^{25}$ Surveillance of underwriting, servicing and construction contract costs was hampered by inadequate appropriations, ${ }^{-\$ \AA}$ political pressure, ${ }^{27}$ and the astounding complexity of the systems themselves. These factors also made impossible the control of rates, despite a Supreme Court ruling in 1930 that the state commissions could inquire into the reasonableness of contract charges by the holding company. ${ }^{2}$ In addition, the commissions, in testing the "reasonableness" of rates, were forestalled from considering any factors that were not related to the "fair value" of the operating properties. ${ }^{29}$ Thus the states were unable to gear consumer costs to the actual value of operating assets or to the legitimate costs of production.

25. Incorporation in a state other than that of the operating company forestalled state commission control of holding company managerial policies. Thus, almost all holding companies were incorporated in states famous for their liberal regulation attitudes. Delaware, of course, was particularly popular. See Legis., 45 HARv. L. REx. 729 (1932), 46 HAnv. L. REv. 508 (1932).

But cf. Rosenbaum \& Iilienthal, Issuance of Securities by Public Scrice Corporations, 37 Y ALE L.J. 716 (1928), for the view that foreign incorporation need not have prevented utility security regulation by the singularly powerful New York State Public Service Commission.

26. See Mosher \& CRawford, Public Utiltry Regulatiox 67-S1 (1933).

27. The political power of the utility interests was significant in almost all state legislatures, regulating commissions, and municipalities. In securing franchises, or blocking enabling legislation it often took the form of bribery and active politieal pressure. Sec Thourpson, Confesstons of tae Power Trust c. LXVIII (1932).

28. Doctrinally, state commissions were practically pow:erless to cone with the holding company problem as it affected their utility rate making efforts. The Supreme Court long withheld the power to inquire into the reasonableness of servicing contracts under the rule of Missouri ex rel. Southwestern Bell Teleph. Co. v. Public Service Commission, 262 U.S. 276 (1923). Not until Smith v. Illinois Bell Teleph. Co., $2 \$ 2$ U.S. 133 (1930), did the Court grudgingly permit contract examination, and then only when there arjeared to be bad faith or the exercise of improper discretion. Mrosuer \& Crawrolin, P(Thic Utilitr Regulation 359-60 (1933). See Lilienthal, Recent Decolopments in the Lane of Pablic Utility Holding Companics, 31 CoL. L. Rev. 189 (1931).

Even after the Smith case, however, commissions were forestalled from really effective regulation by the fact that they could not pass on the reasonableness of holding company" accounting practices. Forced to rely on the judgment of the industry itself, commissions were unable to take account of asset-write-ups in deciding what was a reasonable return. See 42 YALE L.J. 941 (1933). And regulation of servicing charges was often made impossible by the absence of a market price against which to gauge them. See 17 MIArg. I. REv. 283 (1933).

29. The crippling "reasonable return on fair value" formula, for rate regulation, first required by Smyth v. Ames, 169 U.S. 466 (1898), was not mitigated as a constitutiona! requirement until 1944, by FPC v. Hope Natural Gas Co., 320 U.S. 591 (1944). For the logical hoop-jumping which the Smyth a. Ames rule foisted upon state publie service commissions see 2 Bongriget, Valuatron of Property $1081-4$ (1937). See also Bunbright, Utility Rate Control Reconsidered in the Light of the Hope Matural Gas Case, 38 Axr. Econ. Rev. Supp. 465 (1948). 


\section{The ACT}

Stimulated by the record of abuses disclosed by the Federal Trade Commission reports of a six-year investigation, ${ }^{30}$ and by the impotency of state regulation, Congress in 1935 enacted the Public Utility Holding Company Act. $^{31}$ The Act subjected both the gas and electric segments of the utility industry to SEC supervision. All holding companies (except intrastate and other exempted companies) were required to register and file memoranda of their history, present operations (both of themselves and their subsidiaries) and capital structures. ${ }^{32}$ The SEC was authorized to regulate future securities issues ${ }^{33}$ as well as transfers of properties, dividend declaration and loans. ${ }^{34}$ Furthermore, the Commission was empowered to impose uniform accounting practices, ${ }^{35}$ scrutinize utility service contracts, and gear these contracts to actual cost. ${ }^{36}$

The heart of the Act, however, was Section 11(b),-the so-called "death sentence." 37 In an effort to achieve a far-reaching reform of the utility

30. See note 4 supra.

Congress also had the benefit of other revealing studies, See Electric Pozer Industry, Control by Power Companies, SEN. Doc. No. 213, 69th Cong., 2d Sess. (1927); Electric Power Industry, Supply of Electrical Equipment and Competitive Conditions, Sen. Doc. No. 46, 70th Cong., 1st Sess. (1931) ; FPC, Holding Company Control or Licensees of the Federal Power CoMmission (1932); Relation of Holding Companics to Operating Companies in Power and Gas Affecting Control, H.R. REp. No. 827, 73d Cong, 2d Sess. (1935) (the "Splawn Report").

31. For the congressional history see 79 Cong. REc. 10508-75, 10819-27, 14620-7 (1935); Comment, Federal Regulation of Holding Companies, The Public Utility Act of 1935, 45 YALE L.J. 468 (1936).

32. Sections 3(a), 3(b) (exemptions), 5(b) (registration requirements).

A holding company is defined by $\S 2(\mathrm{a})(7)$ as a person holding $10 \%$ of the voting stock of or exercising a "controlling influence" over an operating company; the latter phrase has received a notably liberal construction. See Comments, 40 Micr. L. Rev, 274 (1941), 51 YALE L.J. 1018 (1942)?

33. Sections 6 and 7.

34. Sections $9,10,12$.

35. Section 13.

36. Section 15. Under this rule the Commission has reformed accounting practice on an "original cost" basis. For the effect of this de-watering on the asset accounts of the American Power and Light Company system, see Bunce, Tue Administration of the Public Uttrity Holding Coarpany Act of 1935, pp. 124-286 (unpublished thesis in the University of Wisconsin Library, 1939). "In no case was the transition so abrupt in spite of the magnitude of the ordered write-downs, as to cause an operating company to be thoroughly reorganized. The senior security holders of the various companies did not suffer as a result of the write-downs or because of the changeover in accounting practices. What loss was taken was taken by the holding company, American Power and Light Company. Fortunately for the security holders the years 1938 through 1947 were years of increasing revenues ... and the lowest interest rates in the history of our economy. By carrying through enormous refunding programs, the operating companies were able to effect great savings of annual fixed charges." Id. at 252-4.

37. General agreement was easily reached in most congressional quarters on all subjects of the Act save $\S 11(\mathrm{~b})$. Here a bitter dispute arose. The Senate demanded the 
corporate structures, it went far beyond mere regulatory provisions. ${ }^{35}$ First, geographic unity of the basic operating companies was prescribed. The properties controlled by each holding company empire were to be limited substantially to those which were part of an "integrated system." 33 Scattered companies could be retained only if they were located in an "adjacent state" and if their divestment were economically inadvisable. ${ }^{29}$ Second, each system was required to simplify its capital structure. Holding company units which injected an element of unnecessary complication and militated against reasonable distribution of voting power were to be eliminated. 41

complete elimination of the holding company as an economic phenomenon in the utility field. 79 Covg. Rec. 9040-65 (1935). The House, however, proposed a bill which gave wide discretionary power to the regulatory commission and failed to contain any provision for required corporate readjustments. 79 CoNG. REC. 10634-42 (1935).

Joint conference resolved the dispute. See Conference Report, H.R. REP. No. 1903, 74th Cong., 1st Sess. (1935). The final version, however, in order to placate the varying views on the subject, was of necessity somewhat amorphous. The result has been to give the Commission an extremely wide discretion in its application under the guise of "congressional" (actually Senate) intent.

38. "[The] other sections of the Act provide for the regulation of many activities of holding companies and their subsidiaries ..., whereas $\$ 11(b)(1)$ is concerned with the existing structures of holding company systems. These structures in and of themselves have been found by Congress to constitute an evil that cannot be met by simply regulating future transactions. ..." North American Co. v. SEC, 327 U.S. 686, 710 (1946).

39. Section $11(b)$ :

"It shall be the duty of the Commission, as soon as practicable after January 1, 193s:

"(1) To require by order, after notice and opportunity for hearing, that each registered holding company, and each subsidiary company thereof, shall take such action as the Commission shall find necessary to limit the operations of the holding-company system of which such company is a part to a single integrated public-utility system, and to such other businesses as are reasonably incidental, or economically necessary or appropriate to the operations of such integrated public-utility system."

40. Section $11(b)(1)$ :

"[T]he Commission shall permit a registered holding company to continue to control one or more additional integrated public-utility systems, if, after notice and opportunity for hearing, it finds that-

"(A) Each of such additional systems cainnot be operated as an independent system without the loss of substantial economies which can be secured by the retention of control by such holding company of such system;

"(B) All of such additional systems are located in one State, or in adjoining States, or in a contiguous foreign country; and

"(C) The continued combination of such systems under the control of such holding company is not so large (considering the state of the art and the area of region affected) as to impair the advantages of localized management, efficient operation, or the effectiveness of regulation."

41. Section $11(b)(2)$ :

"To require by order, after notice and opportunity for hearing, that each registered holding company, and each subsidiary company thereof, shall talie such steps as the Commission shall find necessary to ensure that the corporate structure or continued existence of any company in the holding-company system does not unduly or unnecessarily complicate the structure, or unfairly or inequitably distribute voting power among security holders, of such holding-company systems. . . ." 


\section{System INTEGRATION}

Of the two requirements-integration and simplification-the holding companies feared the former far more than the latter. Unlike simplification, integration would require the divestment of important segments of most systems, thus substantially reducing their size. The purpose was to make state regulation effective by returning operating control of the utility industry to local interests, and to effect more efficient grouping of operating properties. ${ }^{42}$ But since this mandate struck at the very root of holding company power, management lost little time in making its interpretation the subject of a bitter dispute.

\section{Functional Unification}

Two problems of immediate importance arose under Section 11(b). The first was under what conditions utilities could retain non-utility enterprises. The second was whether an integrated system could contain both gas and electric utility properties.

At the time the Act was passed, holding company control had by no means stopped at the confines of the utility industry. Almost all holding companies had succeeded in securing dominating voting interests in other businesses in their service area. ${ }^{43}$ Most of these enterprises could claim little or no functional relationship to gas and electricity production. This tended to dilute the energies of management, and greatly to expand the possibilities of abuse in areas where state regulation was non-existent. In 11(b)(1), therefore, Congress permitted retention of "other businesses" only when retention was in the public interest or necessary for the protection of investors and consumers and "not detrimental" to system operation. ${ }^{44}$

Interpreting this clause, the Commission imposed two conditions for retention by a utility system of non-utility enterprises. The holding company

42. Blair-Smith \& Helfenstein, A Death Sentence or a Ncze Lease on Life, 94 U. or PA. L. Rev. 148, 154 (1945).

43. "Through holding company control the electric and gas utility compranies became affiliated with an almost limitless variety of unrelated business activities. Among these were water, gas, ice, street railway, coal oil, real estate and investment companies. There were manufacturers of brick and tile, iron fence, wood products and paper. There were companies operating farms, quarries, gas stations, parking lots, theatres and atnusement parks. There was one cold-storage plant in Alaska and the New Orleans Bascball Co., Inc.” 15 S.E.C. ANN. REP. 91 (1950). Insull, for instance, after securing control of an important segment of the electric power industry in New England, procceded to purchase or build a considerable number of textile factories in order to provide a constant market for his product. Smith, New England Holding Companies, 25 J. LaNd \& P.U. ECon. 289 (1949).

44. Section 11(b): "The Commission may permit as reasonably incidental, or economically necessary or appropriate to the operations of one or more integrated publicutility systems the retention of an interest in any business (other than the business of a public-utility company as such) which the Commission shall find necessary or appropriate in the public interest or for the protection of investors or consumers and not detrimental to the proper functioning of such system or systems." 
had to show that the other business had a distinct functional relationship to the operations of the retained utility properties, ${ }^{45}$ and, in addition, that retention would contribute to operating economies. The SEC has held that retention is "in the public interest" only when it can be shown that the consumer rates will be favorably affected by the economic relation between the principal system and the non-utility properties sought to be kept."s

The Commission has found the necessary functional interconnection in the case of a steam heating plant owned by a holding company where the operating processes of the principal utility are employed by the retained non-utility, ${ }^{47}$ and in the case of a coal mine operated primarily for the benefit of utility units producing manufactured gas or electricity. ${ }^{43}$ It has also approved retention of "other businesses" which could not be operated profitably as an independent entity, but whose continued existence was nevertheless in the public interest. ${ }^{49}$

The second question of primary importance was whether Section 11(b)(1) permitted retention of both gas and electric properties within a single integrated system. ${ }^{50}$ The Commission gave its final answer in $19+1$, in the

45. United Gas Improvement, 9 S.E.C. 52 (1941), aff'd, 138 F.2d 1010 (3d Cir. 1943). The Commission has held that this interpretation is not satisfied by such factors as long established association, profitability of interconnection, economies from joint use of personnel and difficulty of disposition. North American Co., 11 S.E.C. 194, 212-13 (19+2). While it has usually required actual physical interconnection, a showing of contemplated future functional relationships was held sufficient in Panhandle Eastern Pipe Line v. SEC, 170 F.2d 453 (Sth Cir. 1948).

46. The Commission requires an affirmative showing of public benefit; retention of the "other business" must be more than merely "compatible" with the public interest. North American Co., 11 S.E.C. 194, 220 (1942).

47. North American Co., 11 S.E.C. 194, 224-5. In this case there was joint use of personnel and facilities. The production operations were closely related in that "[d]uring the summer, hydro-electric generation had to be supplemented by steam generation because of low water conditions. At that time the demand for steam for heating purposes was low. When the hydro-capacity increased in winter, less steam generation was required, yet the boilers could be kept in continuous operation to supply additional steam required for heating purposes." Klingaran, The Physical Istegratron of the Public Utility Holding Colipanies Since 1935, pp. 364-5 (unpublished thesis in University of Wisconsin Library, 1949). See Engineers Public Service Co., 12 S.E.C. 41 (ice plant retained which was subservient to the utility operations in that the ice was a by-product of cooling and heating the holding company's service building).

48. North American Company, 11 S.E.C. 194, 225-S (1943) (retention of coal mine permitted as an adjunct to the railway which carried the coal to the generating plants). See Cities Service Power and Light Company, 14 S.E.C. 28, 67 (1943) (retention oi certain ditch companies along the Colorado River permitted since they owned the water rights necessary to supply condensing water to the steam boilers of the principal utility): Engineers Public Service Company, 12 S.E.C. 41, 54-5 (1942) (electric appliance sales company retained). But see Arkansas Natural Gas Corp. v. SEC, 154 F.2d 597 (5th Cir. 1946) (retention of oil business denied on the ground that oil production had no functional relation to the system's gas business).

49. See Philadelphia Co., SEC Holding Co. Act Release No. \$242, June 1, 1948.

50. It was common for utility companies, both operating and holding, to cumbine gas 
Columbia Gas and Electric Corp. case. ${ }^{51}$ It decided that an integrated system could be engaged in the production and distribution of only one product. This interpretation was based on the fact that the two industries were for the most part operated as separate and distinct businesses. Moreover, "the very nature of the properties involved"-the different production, distribution and servicing facilities required for gas and electricity-rendered them incapable of physical interconnection. ${ }^{52}$ Thus the SEC, with Supreme Court

and electric operations. In fact, "[s] tate commissions, even in states generally conceded to have reasonably effective regulatory set-ups (among them California, Massachusetts, New York and Wisconsin) saw in this nothing fundamentally opposed to the public weal." Klingman, The Physical Integration of the Public Utidtry Holding Companies SINCE 1935, p. 244 (unpublished thesis in University of Wisconsin Library, 1949). The first SEC decision applying the integration mandate to such a holding system, American Water Works and Electric Co., 2 S.E.C. 972 (1937), quite naturally, therefore, permitted retention of gas properties by a predominantly electric utility company. Apparently stimulated by the cooperation of this company, which had been the first to file an 11 (c) plan, and by Commissioner Douglas' desire to stimulate other companies to enter the $\$ 11$ arena, the Commission gave an extremely generous ruling. It held that "[o]n the basis of the facts presented by this record, it would appear that the electric operations of American Water Works \& Electric Company's subsidiaries conform to the provisions of paragraph (A) in section 2(a) (29)... . The evidence adduced in this case warrants the conclusion that the combined electric and gas operations are so interrelated as to justify this Commission's findings that the two types of public utility enterprises carried on by the applicant's subsidiaries constitute together a single public utility system." 2 S.E.C. $972,983$.

51. 8 S.E.C. 443 (1941). Columbia was predominantly concerned with gas production. Its electric properties, the most important of which were in Dayton and Cincinnati, were somewhat removed from the gas service area in central Ohio. It presented an exhatstive brief, however, to the effect that its mixed properties, including some twenty gas companies, constituted an integrated system on the basis of the precedent established by the American Water Works case. 8 S.E.C. 443, 450-1. See note 50 supra. The Commission, however, had undergone a change of heart since the departure of Commissioner Douglas and the advent of Commissioner Jerome Frank. It distinguished its previous decision on the ground that "in that case the gas operations were small and relatively inconsequential and the opinion is susceptible of the construction that the conclusion was rested not upon a view as to a single integrated system contrary to the views herein expressed, but upon the satisfaction of the standards applicable to additional integrated public utility systems" under the $A B C$ escape provisions. See pages 1101-05 infra. 8 S.E.C. 443, 463-4. The "inconsequentiality" of the gas operations, however, has since been held not sufficient to bring a mixed system under the Water Works rule. Virginia Electric Power Co. \& Gulf States Utilities Co., 9 S.E.C. 461 (1941).

The Commission fortified its conclusion on the somewhat unconvincing ground that Congress, while separately defining an integrated gas and an integrated electric system, made no mention in $\$ 2(2)(29)$ of integrated mixed holdings. 8 S.E.C. $443,462$.

The decision was reaffirmed in the important United Gas Improvement Co. casc, 9 S.E.C. 52 (1941). United brought into issue the question of retainability under the ABC escape provisions, see page 1101 infra. The Commission held that if the mixed propertics could meet these strict requirements, divestment would not be required. 9 S.E.C. 52,81 . See Comment, 50 Yale L.J. 1045 (1941).

52. The North American Co. case, 11 S.E.C. 194 (1942), illustrates the strictncss of this interpretation. North American controlled gas and electric propertics whose service 
blessing, ${ }^{53}$ sacrificed the privilege of holding company control to the interests of management economies.

\section{Geographic Integration}

In satisfying the integration requirement for separate gas and electric utility systems imposed by Section 11(b)(1), the SEC has essentially equated integration with geographic unity of a service area. ${ }^{\text {bs }}$ Generally, holding company control is limited to a principal system whose production units are actually physically interconnected by existing transmission or pipe lines and centrally operated without reference to separate corporate ownership.ss The Commission has justified its interpretation on the ground that only a unified service area permits production and transmission operations to be carried on at their maximum efficiency..$^{65}$

Size alone and existing transmission lines, however, are not completely determinative of the permissible area of the principal sy'stem. A wide range of other factors are considered. For example, the SEC recognizes that the physical aspects of local geography affect the efficiencies of long-range product transmission and limit the placement of generating facilities using natural

areas were almost exactly contiguous. The managements of both industries were closely unified as to advertising, sales promotion, general and payroll accounting, engineering, construction and equipment purchasing. North American's counsel was therefore able to present a convincing argument that here, at least, was an integrated mixed system. Nonetheless, the Commission held that the gas properties could be retained only if they satisfied the ABC requirements as to "additional systems." 11 S.E.C. 194, 216. See pages 1101-05 infra.

53. North American Co. v. SEC, 327 U.S. 686 (1946).

54. The Commission has at times placed considerable emphasis upon the mere factor of size. The fact that the Commonwealth and Southern system had a service area of some 111,000 square miles, despite its efficient transmission system, seemed to indieate to the 1941 Commission the desirability of dissolving it. SEC, REpost of rae Puble Utritty Division of the Securities and Exchange Consarsssron wirn Respect to the Holding Contpany Systear of the Conoronwealth and Soutarm Conforation (1941).

55. Transmission facilities alone are not sufficient: "integration" is found only in situations where properties are employed in coordinated operations. Thus in the Columbia Gas Company case the Commission required divestment of Texas property some 800 miles distant from the primary system in Ohio. While a gas line connected the Texas Corporation with the main operating cluster, the main valve was scldom open; therefore, the Commission concluded, the Texas property was not part of a coordinated system. Columbia Gas and Electric Corporation, 11 S.E.C. 80, 81-2 (1943).

56. Commissioner Douglas early announced this "business-like" approzch towards 11(b) (1). Speaking to the American Bar Association in July, 193S, be said, "An integrated system, as defined by the Act, essentially depends upon engineering and economic facts. Basically, it is an aggregation of units which may be economically operated as a single coordinated system in a single area or region, whether or not that resion is in more than one state. This is not a Procrustean, arbitrary definition. It depends on cconomic facts." Douglas, The Case for Integration in Desrocracy asid Framsice 161 (Allen ed. 1940). 
water power. ${ }^{57}$ In addition, it has considered as relevant the consumption requirements of a system's service area. A number of scattered demand points ${ }^{58}$ and a large daily fluctuation in product consumption require the carrying of a high service load. ${ }^{69}$ In such a situation, the Commission has permitted control of a widespread service area in the interests of utility production economies. ${ }^{60}$

The area of the integrated system may be further broadened if it can be shown that future interconnection will make a particular outlying property part of the economic unity of the principal system. This connection must not only be contemplated but must also be economically desirable. ${ }^{01}$ Thus, in many cases, the Commission has refused to permit the retention of outlying satellites even though connection with the principal system was potentially possible. ${ }^{62}$ Furthermore, the SEC has held that an outlying property, to be retained, must be capable of physical interconnection not only with the main cluster but also with all other separate companies sought to be kept as part of the integrated system..$^{63}$ The fact that such an outlying

57. The Commission has not always considered it necessary to cvaluate the technical aspects of any given set-up under the integration requirements of the Act. Records of proceedings indicate that little importance was attached to the factors of service load or distance transmission limitations until 1941. KLingman, The Physical Integration of the Public Utiltry Holding Conspanies Since 1935, p. 170 n.15 (unpublished thesis in the University of Wisconsin Library, 1949). Engineers Public Service Co., 9 S.E.C. 764,773 (1941) (load factor considered for the first time).

Cities Service was allowed to retain the Cheyenne Light, Fuel and Power Co. despite the fact that the only transmission line connecting it with the principal system was owned by the Bureau of Reclamation. Cities Service Power and Light Co., 14 S.E.C. 28, 53 (1943). Generally, however, the SEC has required that the transmission lines be owned by the holding company system itself. North American Company, 11 S.E.C. 194, 242-3 (1942).

58. In the Ione Star Gas Company case, 12 S.E.C. 286 (1943), the fact that the system served 261 towns covering almost all of Texas and important segments of Louisiana and Oklahoma did not prevent a finding of integration in view of the necessity for a coordinated management over such a large area in order to make service profitable. Sce Lone Star Gas Co., SEC Holding Co. Act Release No. 3865, Exhibit C, October 21, 1942.

59. The load factor is measured by the ratio of average demand for a given period to maximum supply required for the same period of time; it thus indicates the intensity of plant use as determined by the consumption demands of the service area. See Mosules \& Crawford, Public Utility Regulation 247 et seq. (1933).

60. See note 32 sipra.

61. Cities Service Power and Light Co., 14 S.E.C. $28,55-6$ (1943).

62. E.g., Southern Union Gas Co., SEC Holding Co. Act Releases No. 3802, September 19, 1942; No. 3803, September 26, 1942.

63. The Commission has based this interpretation on the definition of an integrated system found in $\$ 2(a)(29)$-that it must, "under normal conditione," be capable of being "economically operated as a single interconnected and coordinated system" (cmphasis added). Cities Service, arguing that physical interconnection of three scparate clusters of properties would satisfy this requirement, implied that mere interconnection alone should be sufficient. The Commission, however, said that integration requires that there be "coordination among all parts, and that those parts be on an integral operating 
unit is geographically separated from the main cluster by intervening areas serviced by another system further militates against retainability. ${ }^{\text {ot }}$

\section{Escape Clauses}

The requirement of an "integrated utility system" is not, however, an absolute one. Systems in addition to the principal system are retainable if the company is able to show simultaneously that (A) they cannot be operated "without the loss of substantial economies," (B) they are located in the same or "adjoining states" and (C) that the "advantages of localized management" are not impaired. ${ }^{65}$ It has been under these ABC escape provisions that the holding companies have argued most strenuously for retention of the far-flung empires.

A. "Loss of Substantial Economies." In almost all cases of forced separation of operating properties, the creation of separate management and servicing departments will entail additional costs. ${ }^{c i}$ The holding companies

relationship to each other." Cities Service Power and Light Company, 14 S.E.C. 28, 55-6 (1943).

64. Engineers Public Service Co., 12 S.E.C. 41, 82-3 (1941). This "anti-gerrymandering" rule was applicable to practically all the holding company systems, for the utilities map prior to 1935 was a patch work. See Utility Corporalions, op. cit. sipro note 4, maps facing p. 56.

65. See note 40 supra. The Commission early held that the clauses are cumulative. It pointed out the fact that they "are in the conjunctive," and that "each must be satisfied to permit retention of additional systems." North American Co., 11 S.E.C. 194, 206 (1942). In addition, it has warned that there is a strong presumption against any systems urging retainability by virtue of the $A B C$ provisions: "It is well settled that the terms of an exception to the general policy of a statute must be strictly constru a against the claimant of its benefit." Engineers Public Service Co., 9 S.E.C. 764, 776 n.24 (1941). Retention has been allowed, therefore, only in the "exceptional" cases. Cf. Standard Power and Light Corp., SEC Holding Co. Act Release No. \$242, p. 12, June 1, 1948.

66. In the North American Co. case, 11 S.E.C. 194, 209 (1942), counsel for the system was able to point to three areas in which considerable savings had been effected through holding company assistance. In financing, both public and through direet intra-system supplies of capital, North American had supplied a staff of trained experts which, it was argued, the separate operating companies would not be able to do. It had also stood ready to loan capital when needed. The Commission held, however, that Clause $A$ required economies not in the system as a whole but solely in the "additional" operating companies sought to be retained. It dismissed North American's argument, thus, by holding that there was no showing of likelihood that these companies could not develop their own financial know-how once independent, or that they could not secure capital at rates at least as low as had prevailed with previous intra-system loans. North Ameriean then pointed to economies resulting from its advisory and consultative services and from the "free exchange of management ideas provided by the intercompany committees and luncheons." The Commission dismissed both of these arguments on the ground that they were not the "important" and "significant" savings which Congress contemplated. North American Co., 11 S.E.C. 194, 209 (1942); Kumgaran, Tue Prysical In:tegrution of the Public Utmitry Holding Coxipamies Since 1935, pp. 180-304 (unpublished thesis in University of Wisconsin Library, 1949). Thus the economies to be shown under 
were therefore able to point to this as a "loss of substantial economies." They urged that a showing of a new operating expense should alone satisfy the requirement of Clause $A .{ }^{67}$

From the beginning, however, the Commission developed a far stricterbut more plausible - interpretation. After divestment, it pointed out, management will be concerned with the production of but a single product in a centralized area. Consequently, increased efficiency will normally result since the conflicts of interests resulting from production of compcting services will be at an end. ${ }^{68}$ The SEC has therefore required holding companies to indicate not only where new expenses will be incurred, but also to show that the predicted increase will not be offset by "compensating advantages." 69 This requirement, that the economic losses be greater than the new savings usually attendant upon the independent operation of a separate integrated system, received recent court approval in Philadelphia Company v. SEC.70

B. "Located in an Adjoining State." Under "Big B" the holding companies made their strongest efforts to escape the rigors of $11(\mathrm{~b})(1)$ integration procedures. They originally argued that this clause permitted the retention of any additional system, and required divestment only of properties which were not located in the same state or states adjoining that of the additional system. In other words, they maintained that it was intended to permit retention of any companies located in any one state or in a series of contiguous states no matter how far removed from the primary system. ${ }^{71}$

B must be tangible operating savings rather than those arising from mere advisory assistance or departmental duplication. Engineers Public Service Co., 12 S.E.C. 41, 62-5 (1945).

67. E.g., Engineers Public Service Co., 12 S.E.C. 41 (1942).

68. Id. at $57-8$.

69. This rule was first announced in Engineers Public Service Co., 12 S.E.C. 41, 62 (1942). There the Commission sharply differentiated between expenses and economies and, on the basis that the latter term was the one employed in the Act, held that congressional intent was to measure the net savings attendant upon continued retention. Increased expenditures of $\$ 125,000$ which were pointed out were not enough since there was no showing that these would not be offset by the economies expected from independence of operating companies not in the main power shed.

70. 177 F.2d 720 (D.C. Cir. 1949).

71. This interpretation, usually designated as the "two-area" doctrine was first presented in the Engineers Public Service Co. case, 9 S.E.C. 764 (1941). Counsel for the system based its argument upon the wording of the statute. They contended that the limitation of additional systems to "one State, or . . adjoining states" needed no antecedent, see note 40 supra; in other words, that the additional systems did not have to be located in the same state or a state adjoining the state of the principal system.

Such an interpretation would, in this case, have permitted Engineers to retain two widely separated property clusters, one centered around Louisiana, the other in Virginia. Both Gulf States Utility Co. and Virginia Electric and Power Co., the two subsidiaries in question, were located in one state and states adjoining that state, although neither touched contiguous states. 
In both the Engineers Public Service Co.72 and the North American Co.73 cases, the SEC developed a different view-subsequently approved by the Supreme Court.74 "Big B," the Commission said, was a compromise provision intended to be subservient to the whole of $11(\mathrm{~b})(1)$ standards and at the same time permit properties not part of the integrated system under 11(b)(1), which were nonetheless not located in a too far distant state, to be retained. And it pointed out that the practical effect of the two-area interpretation urged by the holding companies, carried to its logical extreme, would nullify the provisions of the integration requirement and permit the control of a system without geographic limits. Therefore, the Commission decided that to comply with the $B$ requirement, all additional properties must be located in the same area as the principal system.75 Under this "single-area" interpretation, any additional public utility system retained by the holding company must be located within the main power shed occupied by the principal system, and must be either in the same state or in a state adjoining that of the principal system.

C. "The Adiantages of Localized MLanagcment." Since all three of the ABC escape provisions must be satisfied, it has been possible to dispose of most problems arising under them by applying the simple test embodied in the

72. 12 S.E.C. 41 (1942).

73. 11 S.E.C. 194 (1942).

74. North American Co. v. SEC, 327 U.S. 686 (1946).

75. In their argument before the Commission, the Utilities Division relied to a substantial degree upon the grammatical peculiarities of the Act. They argued, for example, that since the geographic standard of $\mathrm{C}$ was in the singular- "considering ... the area or region affected." - the "additional systems" mentioned in Big B would have to be located in one region or area. They also argued that a strict interpretation of the escape provisions generally was necessary in order effectively to further the integrated standards posited in Section 2(a) (29). Engineers Public Service Co., SEC File No. 59-4, "Public Utilities Division AIemo." 18-24 (1942).

Undoubtedly the prime consideration of the Commission was a fear that if the two area interpretation were adopted, the exception would run away with the rule. But the effect of its interpretation has been practically to reword the section. As it now stands, it is to be read: "(B) All of such additional systems are located in a state is which the sirgle integrated systent operates, or in states adjoining such a state, or in a foreign country contiguous thereto." Engineers Public Service Co., 9 S.E.C. 764, 777 (1941) (emphasis added).

In the North American Co. case, 11 S.E.C. 194 (1942), utility counsel argued a third interpretation, to the effect that under the Commission interpretation that each of the additional systems must be located in a state adjoining a state in which the principal system is located, B would be satisfied if the additional system were located at one end of a state which, at the other end, adjoined the state of the principal system. This "chain interpretation," had it been honored, would have permitted the retention of properties in Mlichigan, which adjoins Illinois, the state of the principal system, only under the forbidding waters of Lalse Mifichigan. The Commission held that such interpretation would "permit the retention of properties from one coast of the country to another, as long as the holding companies retained property in each state in the chain of states." Thus this "chain interpretation, lilie the "two area rule," fell before the Commission's intense regionalism. 11 S.E.C. 194, 203 (1942). 
Big B one-area rule. ${ }^{76}$ The retainability of scattered properties can readily be ascertained under this clause by merely looking at a map of the holding company system. However, in a few situations where an additional system qualifies under the $\mathrm{B}$ requirement, the Commission has been forced to invoke Clause $\mathrm{C}$.

"The advantages of localized management," however, has proved to be an extremely amorphous phrase. In order to arrive at a somewhat tangible interpretation, the Commission has been forced again to adopt geographic standards. Almost the only practical significance the Commission has been able to pump into the phrase has been the distance of an operating concern from the controlling holding company's headquarters. Thus, it has emphasized through graphic illustration the presence of what it calls "absentee ownership." 77 The SEC has held that in the light of the general congressional intent to achieve functionally unified utility systems, Clause C prohibits retention of such units as are not in the main power shed and are dominated by a New York management group far removed from the corporation's service area. ${ }^{78}$ This interpretation of Clause $C$ practically parallels that of Clause B, except that state boundaries need not be, and are not, considered. ${ }^{79}$

\section{Corporate Simplification}

Prior to the Act, most upper-tier holding companies were seriously overcapitalized with nonvoting bonds and preferred stocks upon which arrearages had accumulated. The earning power of over-inflated operating assets had proved unable to support the weighty security systems erected upon them. ${ }^{80}$ Congress apparently felt that simplification of these capital structures was imperative if the utility industry was to be able to effect further financing. ${ }^{82}$ It therefore required in Section $11(\mathrm{~b})(2)$ that registered holding

76. See Blum, SEC Integration of Holding Company Systcms, 17 J. LAND S P.U. EcoN. 423, 427-36 (1941). Thus the important cases of the United Gas Improvement Co., 9 S.E.C. 52 (1941), and the North American Co., 11 S.E.C. 194 (1942), were decided solely on the basis of "B."

77. SEC, Charts Showing Location of Operating Electric and/or Gas Sullsidiaries of Registered Public Utility Folding Companies (1939). The Commission first used this "absentee ownership" argument in Engineers Public Service Co., 9 S.E.C. 764 (1941). They pointed out that retention of the additional systems requested would create a service area over 500 miles broad. In North American Co., 11 S.E.C. 194, 213 (1942), the Commission held that mere breadth of service area was sufficient indication that the advantages of localized management would not be secured, despite the fact that North American's policy had consistently been to permit as much local autonomy as possible.

78. E.g., Engineers Public Service Co., 12 S.E.C. 41, 66 (1942). See, for the "congressional intent," SEN. REP. No. 621, 74th Cong., 1st Sess. 11-12 (1935).

79. It has been under this clause that the Commission has most strongly expressed itsclf against size per se. See Engineers Public Service Company, 12 S.E.C. 41, 66-88 (1942).

80. See SEC, Report on the Study and Investigation of the Wolk, Activities, Personnel and Functions of Protective and Reorganization Comautrees, Part VII, Management Plans Without Aid of Committees 123 et seq. (1938).

81. See Sen. Rep. No. 621, 74th Cong., 1st Sess. (1935). 
companies simplify their corporate structures where holding company units "unnecessarily complicate the system," where voting power is inequitably distributed and where there are more than two levels of holding companies above the operating base. ${ }^{82}$

\section{Unnecessary Complication}

The Commission has interpreted the clause barring unnecessary complication in capital structures as essentially an attack on the continued existence of the "paper corporations" which serve no purpose other than that of facilitating control with a minimum of investment. The absence of useful function is patent when a corporate unit possesses no large, independent staff and does not have its own separate office. ${ }^{83}$ Such units are incompatible with sound financing. In addition to constituting a useless income tax expense, ${ }^{84}$ they force the filtering of profits through successive layers of prior security claims before reaching the equity stocks at the apex corporation.

82. The Commission is ordered, by $11(\mathrm{~b})(2)$ to take action "in order that such holding company shall cease to be a holding company with respect to each of its subsidiary companies which itself has a subsidiary which is a holding company." This clause designated by the SEC as the "great-grandfather" clause, see United Light and Power Company, 10 S.E.C. 945 (1941), has involved little interpretation since it is by far the least ambiguous of the Act's standards. Its application, therefore, has been mechanical and of little interest doctrinally. For an example, see North American Light and Power Co., 10 S.E.C. 924 (1941).

83. One week before the effective date of the Act (December 1, 1935), Elcetric Bond and Share, fearful of this provision, initiated a broad reorganization of its system control mechanism. For the first time, National Power \& Light Co, American Power \& Light Co., and Electric Power \& Light Co., its three major holding company subsidiaries, vere taken out of the filing cabinet and given their own officers and staff. Each was assigned a separate suite of offices in the Bond and Share Building in New York. The interloeling directorships were terminated. This effort to escape the "unnecessary complication" clause of the Act failed, however, not only because of the fact that these corporations still excreised no function as corporate entities, but also because the court was probably impressed with the fact that their directors were unable, in spite of the new nominal independence, to exercise independent judgment. Bond and Share still owned 20.7\%, of the voting securities of American, cast an average of $36.9 \%$ of the total votes cast in stodtholders mectings from 1935 to 1941 and, with management proxy committees, cast $99.9 \%$ of the votes cast at these same meetings. Bunce, The Adaninistration of the Public Utillty Holdisc CosiPANY ACr of 1935, pp. 76-7 (unpublished thesis in University of Wisconsin Library, 1949). The Commission held that the attempt to breathe life into these corporations did not satisfy the Act. SEC Holding Co. Act Release No. 3750, p. 49, August 24, 1942. And this finding was upheld by the Supreme Court in American Power \& Light Co. v. SEC, 329 U.S. 90 (1946). The Court justified the dissolution requirements constitutionally by holding that "nothing of real value" was destroyed. 329 U.S. 90, 116.

84. See Community Gas \& Power Co., SEC Holding Co. Act Release No. 4395, July 3, 1943. The tax costs of American Power \& Light Co., a Bond \& Share subsidiary, for instance, were greater than all other non-financial expenses in 1946. Aloodr's Puncic UrizITIES, 1947, p. 1149.

It should be noted, however, that such intercorporate dividends are accorded an $85 \%$ credit against income tax claims. INr. REv. Cons $\$ 26(b)$. 
Thus they only serve to magnify the effect of a slight drop in operating revenues by causing upper preferred dividend arrearages. ${ }^{85}$ And where these uneconomic complexities exist, the potential investor is precluded from making an accurate estimate of the prospective earning power of the corporation's securities. ${ }^{86}$ As a result, the ability of a system to attract new capital is seriously impaired.77 Therefore, the SEC-persuaded that these "paper corporations" are not only useless but actually burdensome-has required their elimination pursuant to the simplification mandate of Section 11(b)(2).

\section{"Inequitable Distribution of Voting Power"}

By requiring corporate simplification where "inequitable distribution of voting power" existed, Congress apparently intended to improve the lot of the upper preferred stockholders who had no voting power to compensate for the extremely speculative nature of their investment. ${ }^{\&}$ Under this mandate, the Commission has refused to approve capital structures where the top holding company, through a negligible investment in voting stocks, exercises complete control over utility operations financed by the much larger investments of disenfranchised preferred stockholders. ${ }^{89}$ In these circumstances, the SEC has required liquidation of holding company units ${ }^{00}$ or their reconstitution on a completely common stock basis. ${ }^{01}$

\section{DIVESTMENT OF INTERESTS}

Under Section 11(e), holding companies themselves are urged to submit reorganization plans which will bring them into compliance with the 11(b)

85. See notes 9 and 10 supra, for the spectlative nature of upper holding company sccurities.

86. Electric Bond \& Share Co., SEC Holding Co. Act Release No. 3750, p. 68, August 24, 1942.

87. E.g., Commonwealth \& Southern Corp., 11 S.E.C. 138 (1942), aff'd 134 F.2d 747 (3d Cir. 1943). "If the way is to be opened for efficient expansion of power facilities attd service on the part of the operating companies, . . . a necessary step in that direction is the clearing away of financial impediments to the system arising out of the parent company's constant need of revenues to support its own top-heavy capital structure and fixed dividend requirements. Commonwealth \& Southern Corp., 11 S.E.C. 364,365 (1942).

88. See Central \& S.W. Utilities Co. v. SEC, 136 F.2d 273 (D.C. Cir. 1943), where dissolution of the top holding company whose capital structure was 85 per cent non-voting preferred was enforced under the inequitable distribution of voting power clause. See Note, 50 YALE L.J. 1228 (1941).

89. SEC Holding Co. Act Release No. 3750, p. 62, August 24, 1942.

90. See, for example, the liquidation of Cities Service Power \& Light, SEC Holding Co. Act Release No. 6865, August 28, 1946.

91. See Commonwealth and Southern Corporation v. SEC, 134 F.2d 747 (3d Cir. 1943) (order that applicant change its capital structure to all common upheld); Electric Bond and Share Co., SEC Holding Co. Act Release Nos. 6121, October 9, 1945, and 6879-1, September 6, 1946, approved and enforced, 73 F. Supp. 426 (S.D.N.Y. 1946) (plan for retirement of $\$ 5$ and $\$ 6$ preferred). 
standards. ${ }^{92}$ Almost all systems falling under the aegis of the Act have taken advantage of this prerogative. Divestment of scattered properties in satisfaction of the integration requirement has been accomplished through either open market sale ${ }^{93}$ or stock distributions to holding company shareholders. ${ }^{94}$ Simplification of holding company structures is carried out by the merger of subholding and operating companies or of holding and subholding companies, ${ }^{95}$ dissolution of intermediate holding companies, 93 and retirement of complicating security issues. ${ }^{57}$

These procedures necessarily entail the distribution of assets-either cash or portfolio securities as the case may be-to existing stoclhholders. The Act, however, orders the Commission to permit only such distribution schemes as are "fair and equitable." ${ }^{98}$ In bankruptcy reorganizations, this phrase-a "term of art"-theoretically requires that prior claims be fully compensated before junior claims are allowed to participate." The principle of "absolute priority" applies not only as between debt and equity

92. For the procedural relationship between the Commission's $11(\mathrm{~b})$ orders and the plans submitted by holding companies under 11 (e), see Northern States Power Company v. SEC, 164 F.2d 810 (3d Cir. 1947) ; Note, 61 HaRv. L. Rev. 1074 (1948).

93. E.g., American Gas \& Electric Co., SEC Holding Co. Act Release No. 6565, April 19, 1946.

94. E.g., Central \& S.W. Utilities Co., SEC Holding Co. Act Release No. 6606, May 9, 1946; Utilities Power \& Light Corp., 5 S.E.C. 483 (1939).

95. E.g., Buffalo Niagara Corp., SEC Holding Co. Act Release No. 6083, September 26,1945 .

96. E.g., New England Public Service Co., SEC Holding Co. Act Release Nos. 7511, June 27, 1947, and 7713, September 15, 1947, approved, 73 F. Supp. 452 (D. AIe. 1947); Philadelphia Company, SEC Holding Co. Act Release No. S242, June 1, 1948, rchicoring derried, SEC Holding Company Act Release No. 8320, June 30, 1948, offd, 177 F.2d 720 (D.C. Cir. 1949).

97. See note 91 supra.

98. "\$ 11 (e).... If, after notice and opportunity, the Commission shall find such plan, as submitted or as modified, necessary to effectuate the provisions of subsection (b) and fair and equitable to the persons affected by such plan, the Commission shall male an order approving such plan. ..."

99. The phrase was first developed by the courts in equity receivership, see Northern Pacific Ry. v. Boyd, 228 U.S. 482 (1913). Congress then adopted it into several seetions of the Bankruptcy Act, notably \$77b(f), 48 Star. 912 (1934), and Chapter X, 52 SrAr. 911 (1938), 11 U.S.C. $\$ 766(3)$ (1946). As interpreted there it has acquircd a specialized meaning. Case v. Los Angeles Lumber Products Co., 308 U.S. 106 (1939), established the full priority of creditors. As regards preferred stoclsholders with liquidation preference, the Supreme Court has held that they must receive "full compensatory provisions for the entire bundle of rights" surrendered. Consolidated Rock Products Co. v. Du Bois, 312 U.S. 510, 528 (1941); Group of Investors v. Chicago, M1., St. P. \& P. R.R., 318 U.S. 523 (1943).

The interpretation of $\$ 5$ of the Interstate Commerce Act, 24 STAт. 3s0 (1887), as amended, 41 Stat. 480 (1920), 54 StaT. 905 (1940), 40 U.S.C. \$ 5 (1946), however, has seemed to imply that the "just and reasonable" criterion required therein for railroad reorganization means an "investment value" standard. See Schwabacker v. United States, 334 U.S. 182 (1948). And see Comment, Streamlined Copilal Readjustment sunder Scetion 20(b) of the Interstate Commerce Act, 58 Y ALE L.J. 1291 (1949). 
securities, but also as between preferred and common stocks. And in determining the value of preferred stockholder interests, dividend arrearages as well as charter-established liquidation preferences are to be treated as fully matured claims. Even though the corporation is continuing in another form, therefore, priorities are to be determined in the same way as if a liquidation were taking place.

The Commission, however, felt that this analogy was inappropriate to reorganization of utility holding company structures under the simplification mandate. Whether arising through voluntary action on the part of shareholders or involuntarily through action of creditors, bankruptcy reorganization is in a real sense an alternative to outright liquidation. But in reorganizations dictated by the congressional requirement of simplification, this is not necessarily the case. Hence the Commission has taken the position that while "fair and equitable" still means "absolute priority" in dissolutions under the Act, "absolute priority" does not in this context require that the contractual rights of preferred stocks and bonds be treated as fully matured. Instead, assets are to be divided among the various classes of securities in accordance with their "actual values as investments in a going concern." 100

The SEC and the courts have agreed on the phrase "relative investment value" as describing the ratio in which security classes are entitled to share in assets. ${ }^{101}$ This figure is based on a series of estimates. Expected earnings and the rate of capitalization of earnings are calculated on the basis of past revenues, the stability of those revenues, prospective economic conditions, interest rates, miscellaneous risk factors, and the effect of the reorganization itself on particular utility security values. ${ }^{102}$ The Commission then makes

100. See In re Pennsylvania Edison Co., 176 F.2d 764 (3d Cir. 1949).

101. The phrase sounds like-and may be like-the doctrine of "relative priority," now discredited in bankruptcy reorganizations. For a discussion of this doctrine, see Bonbright \& Bergerman, Two Rival Theories of Priority Rights of Sectrity Holders in a Corporatc Reorganization, 28 CoL. L. REv. 127 (1928) ; Bonbright, VALuatron of Property 867-73 (1937).

102. The validity of the Commission's findings as to the "equitable equivalents" of some commion stocks has been vigorously attacked, particularly by Commissioner Healy. For his dissenting opinions see Note, 93 U. of PA. L. REv. 317 n.48 (1945). Criticism is based on the ground that projection of earning power over as much as twenty or thirty years becomes too speculative to permit a reasonable basis for value estimates. Cort1missioner Healy does not question the proposition that it is mathematically possible to estimate the present dollar value of future income. His criticism is lodged, rather, against the Commission's claim of prescience in forecasting future dividends. For instance, in Southern Colorado Co., SEC Holding Co. Act Release No. 4501, p. 18, August 23, 1943, the Commission held that Class A stock, although currently high and dry, would receive dividends "in a number of years," and that therefore it was entitled to a $5 \%$ distribution. Healy clarified the time factor thus: "Let us see how long it would take to eliminate the dividend arrearages. The pro forma estimate of net income of $\$ 312,000$ exceeds the sunnual preferred dividend requirement of $\$ 297,612$ by $\$ 14,388$. Arrearages outstanding on the preferred stock were $\$ 1,367,598$ at October 31,1942 . Thus, even if all earnings could 
an estimate of common's reasonable expectation of dividends by taking into account the time which would have been necessary for liquidating preferred arrearages. The ratio of this estimate to the dividend possibilities of preferred establishes the proportion governing asset distribution. ${ }^{103}$ The reasonableness of this figure then has been incidentally tested against the current market values of the securities. And since current market values of common may have been over-inflated by hopes of a favorable SEC determination, the Commission has further checked its estimates against the open market values of similar utility investments. ${ }^{104}$

The Supreme Court approved this construction of the "fair and equitable" requirement in the Otis case. ${ }^{105}$ At stake was a plan for distributing portiolio securities to preferred and common stockholders of United Light and Power, which was to be dissolved. These securities were valued at $\$ \$ 1,000,000$. Power's charter provided that on "dissolution or liquidation" preferred should receive par $(\$ 100)$ plus dividend arrearages before common shared in the assets. If this provision had been recognized, preferred claims would have totalled over $\$ 98,000,000-\$ 60,000,000$ in liquidation value and $\$ 38,000,000$ in accrued dividends-and common would have received nothing. But the Commission held that the charter provision was inapplicable to dissolution under the Act, and on the basis of "relative investment values" it gave common 5.48 per cent of the portfolio securities. The Court approved the plan on the ground that the charter provision did not contemplate reorganization under the Holding Company Act, and that Congress, in passing the Act, did not intend "that its exercise of power to simplify should mature rights, created without regard to the possibility of simplification. . . ." 1cs

be paid out (an impracticable assumption), it would take 95 years to pay off the arrearages. ... When common stock cannot be expected to participate for so many years I do not believe it has a value." Id. at 36. The Commission has admitted that its prognostications run as far ahead as fifteen years, Virginia Public Service Co., SEC Holding Co. Act Release No. 4618, October 15, 1943, and, perhaps, thirty-fise years, Puget Sound Co., SEC Holding Co. Act Release No. 4255, April 27, 1943.

103. E.g., Portland Electric Power Co., SEC Holding Co. Act Release No. 5470, December 7, 1944; Utilities Power \& Light Co., 5 S.E.C. 483 (1939), plon approred, 29 F. Supp. 763 (N.D. Ill. 1939).

Equitable factors also bear on the distribution ratios in addition to the fair investment value. Intra-system transactions are examined to see if there has been such inequitable treatment of the subsidiary by the parent to satisfy the subordination of the latter's claims to those of other outside security holders, under the rule of Taylor v. Standard Gas \& Electric Co., 306 U.S. 307 (1939) (the "Deep Rock" case). Probably the most important consideration of these "Deep Rock" questions was Ogden Corp., SEC Holding Co. Act Release Nos. 9139, June 7, 1949, and 9202, July 1, 1949. Comparable issues of inequitable dealing were considered in SEC v. Chenery Corp., 318 U.S. 80 (1943), 332 U.S. 194 (1947) (management stock dealing during reorganization proceedings); Note, 57 YALE L.J. 881 (1948).

104. Engineers Public Service Co., SEC Holding Co. Act Release No. 7041, December 4, 1946.

105. Otis \& Co. v. SEC, 323 U.S. 624 (1945).

106. 323 U.S. $624,637-8$ (1945). 
Instead, the "equitable equivalent" of a security's investment value on a going concern basis was properly the measure of a shareholder's rights in an 11 (b) liquidation. ${ }^{107}$

The effect of this interpretation of "fair and equitable" has been, in most cases, to deny preferred its full retirement value and thereby to give common a small share of the assets. ${ }^{108}$ Similarly, debenture holders have been refused their call premiums where market prices had been perennially below par. ${ }^{109}$ On the other hand, preferred stockholders have occasionally received more than they would have under a "liquidation" standard. Where existing assets at the time of dissolution indicate that investment value exceeds the involuntary call price at maturity, the Commission has awarded preferred stockholders the voluntary call premium. ${ }^{110}$

In short, the Commission has attempted to insure that the various security-holders come out of the simplification process holding the same legitimate stake they had when they went in.

\section{The EFfect of 11(b) on Industry, Consumer, Investor}

During the Act's fifteen-year history, there has been substantial progress in making holding company systems comply with 11 (b) standards. ${ }^{111}$ Litiga-

107. Needless to say, this is a fairly flexible standard and the scope of review permitted the courts adds to the freedom enjoyed by the Commission in $\$ 11(\mathrm{~b})$ distributions. In SEC v. Central-Illinois Corp., 338 U.S. 96 (1949), the Court overruled the third circuit's holding that it was entitled, as a court of equity, to exercise full and independent judgment, and that the action was to be tried there as a trial de novo. See Engineers Public Service Co. v. SEC, 168 F.2d 722, 729 (3d Cir. 1948); Notes, 61 Harv. L. Rev. 1262 (1948); 43 ILt. L. REv. 882 (1949). The Supreme Court expressly held that appeals from \$11(b) proceedings were entitled to the same presumptions as those under $\$ 24$ : the Commission's findings are to be sustained if supported by substantial evidence and not contrary to law. 338 U.S. 96, 113-129. See Dodd, Preferred Sharcholdcrs Rights-The Engineers Public Service Company Case, 63 HaRv. L. REv. 298, 300-2 (1949).

The decision as to which of several legally acceptable plans is to be carried out is also to be made by the Commission. American Power and Light Corp. v. SEC, 329 U.S. $90(1946)$.

108. E.g., Northern States Power Co., SEC Holding Co. Act Release Nos. 7950, December 23, 1947, and 7976, January 30, 1948, approved, 80 F. Supp. 193 (D. Minn. 1948); United Light and Power Co., SEC Holding Co. Act Release No. 4215, p. 19, April 5, 1943.

109. See N.Y. Trust Co. v. SEC, 131 F.2d 274 (2d Cir. 1942). In In re Standard Gas \& Electric Co., 151 F.2d 326 (3d Cir. 1945), the court justified such a denial on the ground that it was not a "voluntary" call which entitles the holders to their premiums, In In re Community Power Co., 168 F.2d 740 (3d Cir. 1947), a distribution plan was allowed which denied to secured creditors a portion of the property pledged to the satisu faction of their claims, and ordered a substitution of other property.

110. Central Illinois Securities Corp. v. SEC, 338 U.S. 96 (1949), discussed in Dodd, Preferred Shareholders' Rights-The Engineers Public Service Company Case, 63 Hanv. L. Rev. 298 (1949).

111. See Ely, The Holding Company Overitatl Now Half Completed, 41 P.U. Fotr. 410 (1948); 15 S.E.C. ANN. Rep. 90-6 (1949). 
tion, originally used as a delaying tactic in urging constitutional questions, ${ }^{112}$ is now concerned solely with the details of simplification and integration plans.

Any evaluation of the success of these plans must recognize that they were effected during the time when the economy was booming and the money market was favorable. But enough evidence is in to indicate that the Act itself has produced impressive benefits for the industry, consumer and investor.

\section{The Industry under the Act}

The capital structure of the utility industry has been revolutionized. During the period from June 30, 1938 to June 30, 1949, 2,152 holding companies have been subject to SEC jurisdiction. 113 Today, only 642 registered systems-representing about thirty per cent of the utility industry-have not achieved the geographic integration and corporate simplification required by the Act. ${ }^{114}$ Assets valued at some $\$ 7,965,000,000$ have been divested under 11 (b) by systems no longer registered, ${ }^{115}$ and some $206 \mathrm{com}-$ panies, with assets of almost four billion dollars, have been separated from one system but remain subject to the Act by virtue of their relationship with another holding company. ${ }^{116}$

The complete elimination of the holding company as a phenomenon of the industry is not, however, contemplated. ${ }^{117}$ The SEC estimates that when

112. The holding companies lost little time, immediately after the Act was passed, in marshalling their forces for an all-out assault upon constitutional grounds. A host of cases immediately appeared in the district courts, many involving the injection into bankruptcy litigation of almost ex parte attacks, but in only one, In re American States Public Service Co., 12 F. Supp. 67 (D. Md. 1935), aff'd sub nom. Burco v. Whitworth, 81 F.2d 721 (4th Cir. 1936), cert. den., 297 U.S. 724 (1936), was the Act declared roid. The test case which got to the Supreme Court was Electric Bond \& Share Co. v. SEC, 303 U.S. 419 (1938). There the Court upheld the registration provisions of the Act under a broad conception of the commerce power. The validity of $11(b)$ was not affirmed, however, until North American Co. v. SEC, 327 U.S. 686 (1946), which held that the divestments required under that section did not violate the Fourteenth Amendment due process clause in that no loss of property was incurred. Rather, the Court recognized, new gains from more efficient local management would be realized.

113. 15 S.E.C. ANN. REP. 91 (1949).

114. Id. at 79.

115. Id. at 92.

116. Id. at 93.

117. Here at least congressional intent is clear. See note 37 supra. The final version of the Act, permitting limited holding company systems, was apparently based on 3 recognition that they can perform legitimate economic services to the utility industry and the consuming public. Centralization of engineering, construction, managerial and fiscal staffs cuts operating costs. And they perform financial assistance by loaning on short terms such emergency capital as is needed for supply bills, by purchasing common stocks and by purchasing for later resale senior securities when the market is temporarily unfavorable. Utility Corporations, op. cit. supra note 4, pp. 118-126. Increased efficieney, in some cases at least, may be expected from larger operating units. Callahan, Is There 
all simplification and integration plans are completed, some integrated holding company systems with six or seven billion dollar asset value will remain subject to the registration requirements of the Act although they have fully complied with 11 (b) standards. ${ }^{118}$

Qualitatively the effect of the Act has been equally impressive. Under the Commission's pragmatic interpretation of the 11(b)(1) integration mandate and the "one-area" rule adopted under "Big B," holding company systems, where they remain in existence, are limited to areas in which engineering analysis has indicated that future physical unification is feasible and desirable. ${ }^{119}$ Consequently, there has been a substantial return of operating control to local management. ${ }^{120}$

The units of properties retained in corporate systems have not been so restricted in area, however, as to impair the centralization advantages which holding companies can legitimately perform. ${ }^{121}$ Considerations of efficiency - both economic and technological - 122 have of ten induced the SEC to per-

Still a Need for Utility Holding Companics, 43 P.U. ForT. 597, 599 (1949). See Lilienthal, The Regulation of Public Utility Holding Companies, 29 CoL. I. Rev. 404 (1929).

It is expected that about 20 holding companies will remain in existence and subject to the registration requirement of the Act. Ely, The Holding Company Ovcrhaul Note Half Completed, 41 P.U. FoRT. 410, 413 (1948). That these companies are performing valuable services is seen from the fact that in 1949 alone, registered parent corporations purchased $\$ 150,000,000$ of the common stock offerings of their operating subsidiaries and made capital contributions of an additional $\$ 67,100,000$. 15 SEC ANN. REP. 85-6 (1949).

118. 15 S.E.C. Ann. Rep. 95 (1949).

119. This is illustrated by the reformation of the North American Company. At the time it registered in 1937, it controlled thirty-six utility and forty-six non-utility subsidiaries in ten states and the District of Columbia. The aggregate value of this empire was more than two billion dollars. Since the decision in North American Co., 11 S.E.C. 194 (1942), aff'd, 133 F.2d 148 (2d Cir. 1943), aff'd, 327 U.S. 686 (1946), it has disposed of all its assets except Union Electric Co. of Missouri and Missouri Power \& Light Co., together comprising a well-knit system operating in St. Louis and environs.

120. For the interesting account of the forced retreat of Samuel Insull from the New England utility field, see Smith, The Regulation of Some Neve England Halding Companies, 25 J. LANd \& P.U. Econ. 289 (1949).

121. See note 118 supra.

122. Economists have generally accepted the proposition that the electric power industry functions more efficiently on a monopoly basis than it wotld under competitive conditions. Since fixed costs per unit of output are comparatively high, the loss from duplicating plant and distribution facilities in any one area would tend to swamp any gain from competition in price. Moreover, the area served by any one plant is physically lim: ited by the progressive rise of transmission costs. Therefore, the natural devclopment of the utility industry is toward a series of area monopolies. Behling, Competition and Monopoly in Public Utility Industries, 35 U. of Irx. Bunt. 5 (1938); Jones, The Relation of Large Scale Production to Certain Costs of Electric Utilities in the Unilcd Stales, 18 J. LaNn \& P.U. Econ. 36 (1942).

To solve the inevitable problem of monopoly, however, the states forced the industry to take, in exchange for freedom from competition, a degree of regulation greater in theory than that demanded of any other business. In place of the law of supply and demand, utility prices have been regulated by the states practically since their inception. 
mit systems serving widespread areas. The Act has become a weapon, not against size per se, but against the bigness which brings with it the ineffciencies of uneconomic scatteration. ${ }^{123}$

Simplification of capital structures has proceeded apace. Through the merger of holding units or dissolution of upper companies, most systems are reduced to two corporate tiers above the basic operating companies. ${ }^{12 s}$ In the process, the expensive but useless "paper corporations" have largely disappeared. ${ }^{125}$ The balance of voting power has been substantially amended in most systems. Common stocks now dominate the capital structures of all the holding companies; fixed charge securities have been virtually eliminated from the upper tiers. ${ }^{126}$

This simplifying process has had salutary effects in many directions.

See Iilienthal, Public Utilities During the Depression, 46 HAnv. L. Kev. 745 (1933). The inadequacies of state regulation, however, have been notorious. See page 1093 supra. Prior to the utility reformation under $11(\mathrm{~b})$, therefore, it was aslied whether a return to competition, despite the necessary increased costs, might not redound to the public benefit. Comment, $A$ Re-ezamination of Competition for Gas and Elcctric Utilitics, 50 YALE L.J. 875 (1941).

123. Although generally basing its decisions at least ostensibly on technical and economic considerations of maximizing operating efficiency, the Commission has not been loath to invoke the "giantism" argument when needed. Cities Service, for instance, submitted an interpretation of the integration requirement which would have justified retention of a vast system, and which was technically difficult to refute. The Commission held, however, that this interpretation "would comprehend hegemonies of holding company control so vast that (under the regional standard) the Act would permit a few holding companies to divide the country. The language of the Act does not permit and Congress did not intend any such a result." Cities Service Power and Light Co., 14 S.E.C. 28, 59-60 (1943). The evidence of congressional intent cited, SEN. REP. No. 162, 74th Cong., 1st Sess. 12 (1935), was anything but clear.

Integrated systems of extensive size, however, have been permitted. The Lone Star Gas Company, for instance, serves an area which includes a large part of Texas, Louisiana and Oklahoma. Ione Star Gas Co., 12 S.E.C. 286 (1942). Probably the largest "integrated" gas system permitted is that of Columbia Gas and Electric Corporation. It covers the geographic areas of western Pennsylvania, all of Ohio and West Virginia, and extends into Kentucky and Indiana. The Commission said, in this regard, "We believe that the unique circumstances of this case justify retention of the three groups of companies notwithstanding that the size of the properties comprising the three groups, both absolutely and relatively, might otherwise lead us to the conclusion that separation would be essential under the standards of the Act." Columbia Gas and Electric Co., SEC Holding Co. Act Release No. 5455, pp. 20-1, November 31, 1944.

124. See New England Power Association, SEC Holding Co. Act Release 1\%o. 6470, March 14, 1946 (merger of two tiers of subholding companies under the "great grandfather" clause).

125. See Electric Power \& Light Corp., SEC Holding Co. Act Release No. 88s9, March 1, 1949.

126. See, for example, the radical reformation of the overcapitalized billion-dollar Associated Gas \& Electric system. The company emerged from $\$ 11$ reorganization in 1949 as the General Public Utilities Corp. with only $\$ 3,950,000$ 6\% bank notes outstanding, the remainder of its security structure consisting of $\$ 122,000,000$ common stoels 15 S.E.C. ANN. REP. 106 (1949). 
Primarily, it has made most unlikely the abuses characteristic of holding company control in the twenties. Extreme leverage power and the stimulus to heavy current returns have disappeared with the elimination of excessive pyramiding and prior preference security financing in the upper levels. Therefore, holding company investment interests are now closely tied to sound operating policy.

Moreover, with conservative security structures, the reformed systems have proven themselves able to attract new capital. ${ }^{127}$ Operating property expansion during the past decade has required a large volume of new investment money which could never have been secured so long as the industry remained seriously overcapitalized. ${ }^{128}$ Corporate reorganization under 11(b)(2) has unfrozen utility financing by wiping out preferred dividend arrearages and thus once again has given the stock of the industry a favorable market. ${ }^{129}$

\section{Effect of the Act on Consumers}

At the time the Act was passed, an important difference of opinion existed as to the effect of divestiture and integration on the ultimate consumer. ${ }^{130}$ The effect seems to have been favorable. Along with reformation of corporate structure, the utility industry has undergone a substantial expansion in operating size and capacity. Electric generation has increased fifty per

127. Present financing volume of only the companies remaining subject to the Act is at the annual rate of $\$ 1,700,000,000$. Only between five and twenty per cent of this new capital is required for the refinancing of funded debt. Moreover, there has been a marked increase in the proportion of common stock offerings as opposed to long term debt securities. 15 S.E.C. ANN. REP. 83-5 (1949). The removal of $\$ 1,500,000$ asset writc-ups from holding company accounts has been one of the factors permitting this wholesale restoration of investor confidence. See id. at 87.

128. See Douglas, Dividends in Arrears in Denocracy and Finance 137 (Allen ed. 1940).

129. The "other businesses" clause of 11 (b) (1) has also had an important effect on the industry. The spread of holding company system control over important segments of the non-utility economy constituted probably the most serious potential political and sociological danger of the holding company phenomenon. Not only did it give to management control in unregulated areas of the economy and substantial leverage in competitive markets-thereby increasing the possibilities for abuse-but it was also "a form of private socialism inimical to the functioning of democratic institutions and the welfare of a free people." Hearings before Committee on Interstate and Forcign Commerce on H.R. 5423, PART 3, 74th Cong., 1st Sess. 2312 (1935). See Fournier, Simplification of Holding Contpanies under the Public Utility Act of 1935, 13 J. Land \& P.U. Econ. 138 (1937). However, the divestments under the "other businesses" clause have not only averted this danger but have also resulted in substantial benefits to the utility industry as a whole by insuring it a management which can concentrate solely on the problems of that industry. See 15 S.E.C. ANn. Rep. 91 (1950).

130. See, e.g., Waterman, Economic Implications of Public Utility Holding Company Operations, 9 Micr. Bus. StudIEs 1 (1941), who gathered copious data in support of his proposition that "residential electric customers of independent utilities pay as much or more for their current than do the customers of holding company subsidiaries." Id. at 140. 
cent since 1935 and annual new utility construction is approximately twelve times the 1935 figure. ${ }^{131}$ The resulting benefits have gone to the public which purchases gas and electricity. In the last decade when consumer revenues increased 220 per cent, rates have fallen between nineteen and twenty-seven per cent.132

Admittedly, this rate reduction has been largely a by-product of the favorable engineering and economic developments of recent years, which were especially stimulated during the war. ${ }^{133}$ The Holding Company Act has, nevertheless, reduced system overcapitalization and concentrated control, and thus has made operating companies increasingly responsive to state regulatory efforts which previously were powerless to protect the public interest.

Unfortunately, few states have taken full advantage of the new amenability of the industry to state regulation. The laxity of utility commissions in most areas has permitted holding company systems, though now reformed on the smaller "integrated" basis, to reduce their rates only a fraction of what Act-inspired economies would have permitted. ${ }^{134}$ A revival of regulatory efforts by a number of states could mean even further savings to the consumer by virtue of $11(\mathrm{~b})$ 's operation.

\section{Effect of the Act on Iniestors}

Before 1929, the factors of leverage and diversified investment were widely advertised as the singular advantages of holding company securities. ${ }^{135}$

131. Electrical World, Jan. 29, 1949, pp. 104, 121.

132. Id. at 105; FPC, Typical Electric BILIS p. VIII (1949).

133. See the quarterly reports in J. LAND \& P.U. Econ.

134. For instance, the Florida Power and Light Company will be subject to no federal jurisdiction in that it is no longer a holding company nor an interstate transmitter of electricity under Federal Power Commission regulation. Yet to return Florida Power to state regulation is an empty gesture; the state has none. In this way, one of the essential purposes of the Act, "to free operating companies from the absentee control of holding companies, thus permitting them to be regulated more effectively by the State" 11 S.E.C. ANN. REP. 62 (1945), is frustrated. Consumer interests might have been better served if Florida Power had been retained in the American Power \& Light system, thus subjecting it to federal regulation.

Bunce fears a kind of "unregulated feudalism" in such contexts, whereby the newly powerful local management, free from the dictates of both holding company and SEC, may adopt policies wholly beneficial only to itself without fear of adverse consequences from moribund state commissions. Bunce, The Adarrnistration of tae PunLic Utruiti HoldING CoMTPANY ACT OF 1935, p. 298 (unpublished thesis in University of Wisconsin Library, 1949).

Of course, some states on the other hand have effective utility regulation. Wisconsin, New York and California, for instance, have established Commissions of adequate power. See FPC, State Conrarisston Jurisdiction and Regulation of Electric atid Gas UtmiTIES (1948).

135. After 1935, this "law of averages" theory became a management argument against full application of the Act. Fogerty, President of North American, and Groesbeck, President of Electric Bond \& Share, wrote to Douglas in 1937 expressing their willing- 
Forced divestment under the 11(b) simplification and integration requirements have destroyed them. Their loss, however, has proven more an asset than an injury. The leverage of upper equity securities was the principal reason for their collapse during the depression, and for the growing arrearages on preferred stocks. "Diversity of investment" merely meant diversity by financial chance and thus all too often a forced interest in an unhealthy concern. ${ }^{136}$ By wiping out undue leverage and permitting holding company investment only in an integrated utility system, the Act has reduced the extremely speculative factor in investment in upper holding companies.

Apprehension was also widespread that investment values would be wiped out following the divestitures required by Section 11(b)(1). It was feared that the forced dumping of these securities on an unsteady market would demoralize the field and depress utility stock prices even below their 1929-32 level. ${ }^{137}$

However, the SEC has carried out simplification and integration plans only where the state of the existing market promised preservation of legitimate investment values. ${ }^{138}$ The result of this policy has been a clear benefit to investors. Market values of holding company securities have shown a steady rise since 1935; the drastic capital changes required by the Act have seldom had a depressive effect on any particular security. Although quoted prices initially went down at the time of registration, the equitable treatment of all stock classes in dissolution has generally brought on a very substantial increase in security values. ${ }^{139}$

Equity stocks of apex holding companies especially have been benefited. Years of dividend arrearages had accumulated on preferred stocks, and the magnitude of these arrearages promised to forestall common stock dividends for many years even under the most favorable circumstances. ${ }^{140}$ The market ness to comply with the Act but expressing "their belief that the fundamental principle of diversity of investment which is represented here by both geographic location of operating properties and character of business served by them, is a very important factor in the raising of additional capital, and that such principles should be preserved in the public interest." Douglas, The Case for Integration in Democracy and Finance 143 n.1 (Allen ed. 1940).

The argument had been effectively punctured by the depression, however. Diversified holding company earnings dropped much more drastically than those of already integrated systems such as Niagara Hudson and Consolidated Edison. Id. at 153-4.

136. See Utility Corporations, op. cit. sulpra note 4, pp. 75-6.

137. See SEN. Rep. No. 621, 74th Cong., 1st Sess. 11-17 (1935).

138. See Okin v. SEC, 145 F.2d 913 (2d Cir. 1944). The Commission has even permitted the temporary formation of holding units which violated the "great-grandfather" clause, see note 82 supra, as a provisional method for carrying out dissolution schemes without the necessity of dumping securities on an unfavorable market. Cf. In re Electric Power \& Light Corp., 176 F.2d 687 (2d Cir. 1949). It has also taken pains to honor management's judgment as to the most favorable divestment time. Engineers Public Service Co., SEC Holding Co. Act Release No. 7041, December 4, 1946; New England Gas and Electric Ass'n, SEC Holding Co. Act Release No. 7181, February 11, 1947.

139. See, for examples, notes 142 and 144 infra.

140. See page 1092 supra. As evidence of the speculative character of these securities, 
value of these equity stocks was therefore very seriously depressed in 1935 14t and the investments of numerous common shareholders were in danger of being wiped out altogether by the reorganization of companies at a time when they were unable to satisfy these prior liquidation preferences.

The adoption by the Commission and courts of the "equitable equivalents" doctrine as determining the ratio of asset distribution on dissolution among the various security classes constituted a distinct benefit to common. As applied, the formula permitted a large return of the actual investment to most shareholders and, in many cases, a very substantial distribution of excess earnings not required for the satisfaction of preferred claims. Common stock values, under the aegis of this favorable prospect, characteristically experienced a revival immediately prior to the contemplated asset distribution. ${ }^{142}$

Preferred stockholders too have fared extremely well. While originally they may have suffered an abstract loss under the Commission's interpretation of "fair and equitable," the "loss" was not large: usually they were deprived of only a small share-between two and eight per cent-of the total remaining assets which theoretically would have been theirs under a Chapter $\mathrm{X}$ type reorganization. ${ }^{143}$ Since then, however, the value of their

the stock values of American Power and Light Company are typical. The original purchase price of common in 1910 was $\$ 42$. In 1929, this stock was selling for \$1,757 on the market. By 1941, the price had fallen back to $\$ 3.75$. Preferred, issued in 1930 for $\$ 107$, was somewhat more stable. Three depression years later it had fallen only to \$10. ALoopy's Puncic UTuITIES, the years cited.

141. See notes 142 and 144 infra.

142. The following are typical of common stock fluctuations: Market Value and Per Cent of Change from Aug. 26, 1935

Electric Power \& Light Co.

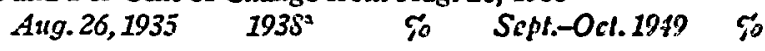

Common stock: $\$ 17,105,810 \quad 36,468,049 \quad 113.2 \quad \$ 99,813,696^{\circ} \quad 483.5$

Engineers Public Service Co.

Common stock: $7,997,991$ $8,594,856$ 107.5 $81,135,441^{\mathrm{e}}$

Commonwealth \& Southern Common stock: $58,928,324 \quad 37,882,494 \quad 35.7 \quad 192,232,623^{\circ} \quad 2763$ a. The registration dates of each company, i.e., March 28 for Commonwealth and Southern, December 1 for Electric Power \& Light, and February 21 for Engineers Public Service Co.

b. Market value of securities received under 11 (e) plan.

c. Present market value of securities received, plus excess of present market of Gulf States Utilities Co. common stock over the price at which it could be purchased in the exercise of rights distributed to stackholders of Engineers Public Service.

SEC, The Public Utility Holding Conipany ACT of 1935, pp. 13-15 (1949).

143. "Theoretically," because it often is doubtful that bankruptcy reorganizations have in fact adhered to the spirit of "absolute priority." See, c.g., Hand \& Cummings, Consensual Securities Modification, 63 HARv. L. REv. 957, 976-7 (1950). Junior claimants may gain a stake in the new company through overly-liberal estimates of future earnings, or through an unduly high rate of capitalization of those earnings-even though the distribution of securities based on that valuation follows "absolute priority." See Billyou, A Decade of Corporate Reorganization Under Chapter X, 49 CoL. L. REv. 456,486 (1949). 
investments has been materially enhanced by the extremely favorable security market and by the conservative capital structures resulting from reorganization. ${ }^{144}$

\section{CONCLUSION}

The "death sentence" of the functionless holding company has been exccuted in an effective and yet singularly fair manner. The excited objections of 1935 to 11(b) have therefore given way to cooperation with enforcement efforts from almost all quarters. "What began as a sensational battle-cry has become the mere nickname of a section number." ${ }^{145}$ Section 11(b) in fifteen years has revolutionized the corporate structure of the utility industry. ${ }^{146}$ Economic reality rather than financial manipulation determines

144. The following table shows a typical rise in preferred stock values for three important holding companies:

Market Value and Per Cent of Change from Aug. 26, 1935

Commonwealth \& Southern:

Aug. 26, $1935 \quad 1938^{\mathrm{a}}$, \% Sept.-Oct. $1949 \%$

$\$ 6$ Preferred

Electric Power \& Light

Corporation:

$\$ 7$ Preferred

$\$ 6$ Preferred

$\$ 78,750,000$

$43,500,000$

$44,8 \$ 166,090,416^{b}$

110.9

$\$ 7$ Second Preferred

$11,311,828$

$18,895,454$

167.0

$97,402,849^{\circ}$

761.1

Engineers Public Service

175.8

$43,987,716^{\circ}$

$13,592,956^{\circ} \quad 1059.9$

Company:

$\$ 6$ Preferred

$\$ 5.50$ Preferred

$1,171,867$

$2,114,985$

180.5

$\$ 5$ Preferred

$2,431,388$

$6,253,498$

$5,109,032$

$\begin{array}{ll}3,445,924 & 141.7 \\ 8,738,093 & 139.7 \\ 6,639,793 & 130\end{array}$

$7,647,840^{4}$

$21,037,072^{4}$

$16,297,482^{4}$

214.5

236.4

218.9

a. The registration date for each company, i.e., March 28, for Conmonwealth \& Southern, December 1 for Electric Power \& Light, and February 21, for Engineers Public Service Co.

b. Cash and market value of securities received. 57,753 shares of preferred were purchased by the company between 1943 and 1949 for a total consideration of $\$ 5,949,840$. This amount is included in the $\$ 166,090,416$.

c. Market value of securities received under $\$ 11(\mathrm{e})$ plan.

d. Cash received in retirement or purchase of securities. SEC, Tine PunLic UTILITY Holding Company Act of 1935 (1949).

"The history of [major holding company dissolutions] is not without its sardonic side. The utility managements have fought the 'death sentence' bitterly; they have tried to cnlist the support of their stockholders to prevent the passage of the act itself, and in their annual reports they have recounted their (unsuccessful) efforts to defeat it in the courts as though they were thereby protecting the interests of the owners of the securities. Yet for years the course of market prices has proclaimed eloquently that the holding-company stockholders would gain and not lose from these dreaded dissolutions. For, once they receive the shares of the operating companies in place of the parent-company securities, the persistent discount on the latter disappears and the aggregate value of what they own is materially improved." GRAHAM, The INTELligent INVESTOR 229 (1949).

145. Blau-Smith \& Helfenstein, A Death Sentence or a Neze Lease on Life, 94 U. of PA. L. REv. 148 (1945).

146. The divestitures required by the Act have also had another effect. "Those wio 
its future growth and concentration. The benefits of utility monopoly are now shared by the consumer, the local operating management and the investing public. ${ }^{147}$

support the advance of public power may find satisfaction in the fact that holding companies faced with 'integration and simplification' and 'dissolution' orders have been much less reluctant to sell operating companies to public power interests than they once were. Assuming that such sales are made under conditions of arm's length bargaining, as they most likely would be, considering the divergent interests of the principals, a social gain is achieved in that the transfer of existing properties forestalls the "necessity of duplicating existing properties." Bunce, The Adarinistration of the Punlic Utility Holdme Compaisy Act of 1935, pp. 289-90 (unpublished thesis in University of Wisconsin Library, 1949).

But cf. King, Nebraska, the Public Power State, 47 P.U. Fort. 357, 419 (1947), expressing the fear that a supposed conspiracy of Wall Street interests was unloading unretainable properties to public power projects at prices far in excess of actual value.

147. The House Judiciary Subcommittee on Mionopoly Power-the Celler Committeehas recently interested itself in the possibility of an anti-monopoly statute for business modeled in general on the Holding Company Act. In fact, Dr. Walter Adams of Mrichigan, during his testimony before the Committee on November 10, 1949, presented a proposed draft for an "anti-monopoly" act which is directly drawn from this source. Hcarings before the House Judiciary Subcommittee on Monopoly Power, Part 2-B, 81st Cong., 1st Sess. 1311-39 (1949). The mandates of $\$ 11$ (b), however, are particularly geared to the utility industry. First, the industry's financial abuses were the product of the holding company phenomenon and its pyramided leverage; this is not true to such a marked degree of monopoly in manufacturing and insurance. See BerLe \& MIEANs, Tue Mfodern Corporation and Private Property 205 (1932) ; Bonbright \& Mfeans, Tue Holding Cospany (1932) passin. Secondly, geographic integration is a valid requirement of the utility business, which is essentially local and monopolistic in nature to begin with. A parallel approach to the evils of industrial concentration in general necessarily requires adherence to a business philosophy based on the desirability of economic provincialism and monopolistic positions for nationally important industries. This, of course, would conflict directly with American ceonomic policy and business reality. Probably the only lesson which the Holding Company Act's success contains for the draftsmen of future federal regulatory statutes is its substitution of positive reorganization mandates for the negative sanctions which have marked our antitrust statutes in the past. See Trienens, The Utility Act as a Solution to Sherman Act Problems, 44 Ind. L. REv. 31 (1949). 